\title{
IMMOBILISASI SUSPENSI AKTIF PADA PELLET AMMONIA OXIDIZERS UNTUK PENGOLAHAN LIMBAH URIN KAMBING MENJADI PUPUK N
}

\author{
Atita Arli Tiara, I Wayan Budiarsa Suyasa*, I Gusti Ayu Kunti Sri Panca Dewi \\ Fakultas Matematika dan Ilmu Pengetahuan Alam, Universitas Udayana Bali \\ *Email: budiarsa_suyasa@unud.ac.id
}

\begin{abstract}
IMMOBILIZATION OF ACTIVE SUSPENSION IN PELLET AMMONIA OXIDIZERS FOR THE TREATMENT OF GOAT URINE WASTE INTO N FERTILIZER
\end{abstract}

Livestock waste that is thrown away without being processed will cause environmental pollution, therefore an effort is needed to process the livestock waste is to be processed into organic fertilizer. The part of livestock waste that can be used as organic fertilizer is urine, in this study goat urine is used. This study aims to find the best nutrients for seeding active suspension, look for the optimal dosage and time for processing goat urine into $\mathrm{N}$ fertilizer. The method used in this study is to immobilized the active suspension into the ammonia oxidizers pellets for later used in the goat urine treatment process with an aeration system, so that a nitrification reaction occurs which results is decrease ammonia and nitrite levels and increase nitrate levels. The results obtained in this study are the nutrients that are best used for seeding active suspension are media II that is 5 grams NPK fertilizer; 2,5 grams $\mathrm{NH}_{4} \mathrm{Cl}$; and 5 grams glucose with MLVSS values of $9000 \mathrm{mg} / \mathrm{L}$ at 18 hours. The processing of goat urine obtained optimal results at pellet dosage of $20 \%(\mathrm{w} / \mathrm{v})$ with optimal time at 18th hour. Ammonia level obtained was $5.6811 \mathrm{mg} / \mathrm{L}$, nitrite levels of $2.3992 \mathrm{mg} / \mathrm{L}$, and nitrate levels of $10.6618 \mathrm{mg} / \mathrm{L}$.

Keywords: Immobilization, active suspension, MLVSS, pellets, ammonia oxidizers, nitrification

\section{PENDAHULUAN}

Limbah ternak dapat dimanfaatkan sebagai pupuk organik untuk tanaman pertanian sebagai upaya mengatasi masalah pencemaran lingkungan. Salah satu bagian limbah ternak yang dapat dimanfaatkan sebagai pupuk organik adalah urin ternak. Penelitian ini menggunakan urin kambing karena urin kambing memiliki kandungan unsur hara $\mathrm{N}$ yang lebih tinggi dibandingkan dengan urin ternak lainnya. Menurut Lingga (1991) urin kambing memiliki kandungan nitrogen (N) $1,50 \%$, fosfor $(\mathrm{P}) 0,13 \%$, kalium (K) 1,80\%, dan air sebesar $85 \%$. Pengolahan urin kambing menjadi pupuk $\mathrm{N}$ dilakukan dengan mengimmobilisasikan suspensi aktif ke dalam pellet yang dibuat dari bahan organik kemudian diaplikasikan pada urin kambing dengan perlakuan aerasi. Berdasarkan penelitian Vanotti dan Hunt (2000) dibutuhkan waktu 14 jam untuk mengoksidasi $\mathrm{NH}_{4}{ }^{+}(210-230 \mathrm{mg} \quad \mathrm{N} / \mathrm{L})$ menjadi $\mathrm{NO}_{3}^{-}$menggunakan pellet Acclimated Lagoon Nitrifying Sludge (ALNS), sedangkan menurut Szogi, dkk (2004) pengolahan air limbah ternak babi yang menggunakan teknologi sel nitrifikasi yang diaklimatisasi dan diimobilisasi dalam pellet polimer memiliki efisiensi lebih dari $90 \%$ dengan waktu pengolahan 12 jam. Berdasarkan uraian tersebut maka pada penelitian ini dilakukan immobilisasi suspensi aktif pada pellet ammonia oxidizers 
untuk pengolahan limbah urin kambing menjadi pupuk N. Penelitian ini bertujuan untuk mengetahui komposisi nutrient yang paling baik untuk pertumbuhan biomassa (MLVSS) mikroorganisme nitrifikasi, untuk mengetahui dosis pellet dan waktu pengolahan yang optimal untuk pengolahan urin kambing menjadi pupuk $\mathrm{N}$.

\section{METODOLOGI}

\subsection{Lokasi dan Waktu Penelitian}

Penelitian ini dilakukan di Laboratorium Penelitian Program Studi Kimia Fakultas Matematika dan Ilmu Pengetahuan Alam Universitas Udayana. Limbah urin kambing diambil dari salah satu peternakan di Jl. Maruti No. 5, Denpasar Utara. Pengambilan sampel sedimen dilakukan di aliran sungai Badung di sebelah peternakan kambing tersebut. Waktu penelitian dilakukan pada bulan Maret 2019 sampai dengan Mei 2019.

\subsection{Prosedur Penelitian}

\subsubsection{Pembuatan Media Pertumbuhan Bakteri Pengoksidasi Amonia}

Media pertumbuhan bakteri pengoksidasi amonia ini divariasi menjadi 3 macam, media ammonia oxidizers I dibuat dari $\mathrm{NaHCO}_{3}(1225 \mathrm{mg}), \mathrm{Na}_{2} \mathrm{CO}_{3}(359 \mathrm{mg})$, $\mathrm{K}_{2} \mathrm{HPO}_{4}(100 \mathrm{mg}), \mathrm{MgSO}_{4} \cdot 7 \mathrm{H}_{2} \mathrm{O}(60 \mathrm{mg})$, $\mathrm{CaCl}_{2} .2 \mathrm{H}_{2} \mathrm{O}(40 \mathrm{mg}), \mathrm{FeSO}_{4} .7 \mathrm{H}_{2} \mathrm{O}(40 \mathrm{mg})$, dan $\left(\mathrm{NH}_{4}\right)_{2} \mathrm{SO}_{4}(300 \mathrm{mg})$, kemudian semua bahan dilarutkan dalam akuades hingga volume $1000 \mathrm{~mL}$ pada gelas beker (Vanotti dan Hunt, 2000)

Media ammonia oxidizers II dibuat dari 5 gram pupuk NPK, 5 gram glukosa, dan 2,5 gram serbuk $\mathrm{NH}_{4} \mathrm{Cl}$. Semua bahan tersebut dimasukkan ke dalam gelas beker dan dilarutkan dengan akuades hingga volume mencapai $1000 \mathrm{~mL}$, lalu diaduk hingga homogen (Pradnyadari dkk, 2018).

Media ammonia oxidizers III ini dibuat dari 5 gram pupuk urea, 2,5 gram pupuk $\mathrm{KCl}$, dan 2,5 gram pupuk TSP dan 2,5 gram glukosa. Semua bahan tersebut dimasukkan ke dalam gelas beker dan diencerkan dengan menggunakan akuades hingga volume mencapai $1000 \mathrm{~mL}$, lalu diaduk hingga homogen.

\subsubsection{Pembuatan Larutan Aktif Ammonia Oxidizers}

Sebanyak 3 buah gelas beker ukuran 2 L yang sudah dibersihkan disiapkan dan diberi label SA1 (suspensi aktif 1), SA2 (suspensi aktif 2), dan SA3 (suspensi aktif 3). Gelas beker SA1 ditambahkan media ammonia oxidizers I yang telah dibuat sebanyak $1000 \mathrm{~mL}$, gelas beker SA2 ditambahkan media ammonia oxidizers II sebanyak $1000 \mathrm{~mL}$, dan gelas beker SA3 ditambahkan media ammonia oxidizers III sebanyak $1000 \mathrm{~mL}$. Masing-masing gelas beker ditambahkan sampel sedimen yang telah diambil sebanyak 10 gram. Ketiga gelas beker tersebut diaerasi dengan menggunakan aerator yang diberi selang lalu ditutup dengan kain kasa dan diikat dengan karet. Pertumbuhan biomassa diamati dengan pengukuran nilai MLVSS (Mixed Liquor Volatile Suspended Solid) selama 3 hari hingga MLVSS mencapai $2000 \mathrm{mg} / \mathrm{L}$. Larutan aktif ammonia oxidizers dengan nilai MLVSS tertinggi akan digunakan untuk pembuatan pellet yang nantinya dapat diaplikasikan untuk mengolah urin kambing menjadi pupuk $\mathrm{N}$.

\subsubsection{Pembuatan Pellet dengan Penambahan Larutan Aktif Ammonia Oxidizers}

Pellet dibuat dari 500 gram ampas tahu dan 250 gram tepung jagung. Larutan aktif ammonia oxidizers dengan nilai MLVSS tertinggi disiapkan sebagai pengganti air. Semua bahan dicampur agar merata, lalu bahan ditambahkan dengan larutan aktif ammonia oxidizers hingga bahan berbentuk adonan. Adonan dimasukkan ke dalam cetakan yang menggunakan pipa pvc berukuran panjang 3 $\mathrm{cm}$ dan diameter $1,5 \mathrm{~cm}$. Tahap selanjutnya adalah pellet dilepas dari cetakannya kemudian diangin-anginkan Pengeringan 
dilakukan dengan diangin-anginkan selama beberapa hari sampai kadar air pellet tidak lebih dari 10\% (Edison dkk, 2011).

\subsubsection{Pengolahan Urin Kambing dengan Pellet Menjadi Pupuk N}

Pengolahan urin kambing dilakukan setelah pellet yang terimobilisasi larutan aktif ammonia oxidizers telah kering dan siap untuk digunakan. Urin yang akan diolah disaring terlebih dahulu dengan kain kasa untuk menghilangkan kotoran berupa padatan yang ikut tercampur ke dalam urin. Urin dimasukkan ke dalam bak pengolahan dengan volume $1000 \mathrm{~mL}$ sebanyak 3 bak dan masing-masing bak berisi $500 \mathrm{~mL}$ urin. Bak 1 ditambahkan pellet sebanyak $10 \%$ (b/v), kemudian bak 2 ditambahkan pellet sebanyak 20\% (b/v), dan bak 3 ditambahkan pellet sebanyak $30 \%(\mathrm{~b} / \mathrm{v})$. Masing- masing bak diberikan perlakuan aerasi dan dilakukan pengambilan sampel untuk pengukuran kadar amonia, nitrit, dan nitrat pada jam ke-8, 12, 18 dan jam ke-24

\section{HASIL DAN PEMBAHASAN}

\subsection{Nilai MLVSS Larutan Aktif Ammonia Oxidizers}

Nilai MLVSS yang diperoleh pada waktu pengolahan dengan perlakuan aerasi selama tiga hari disajikan pada Gambar 1.

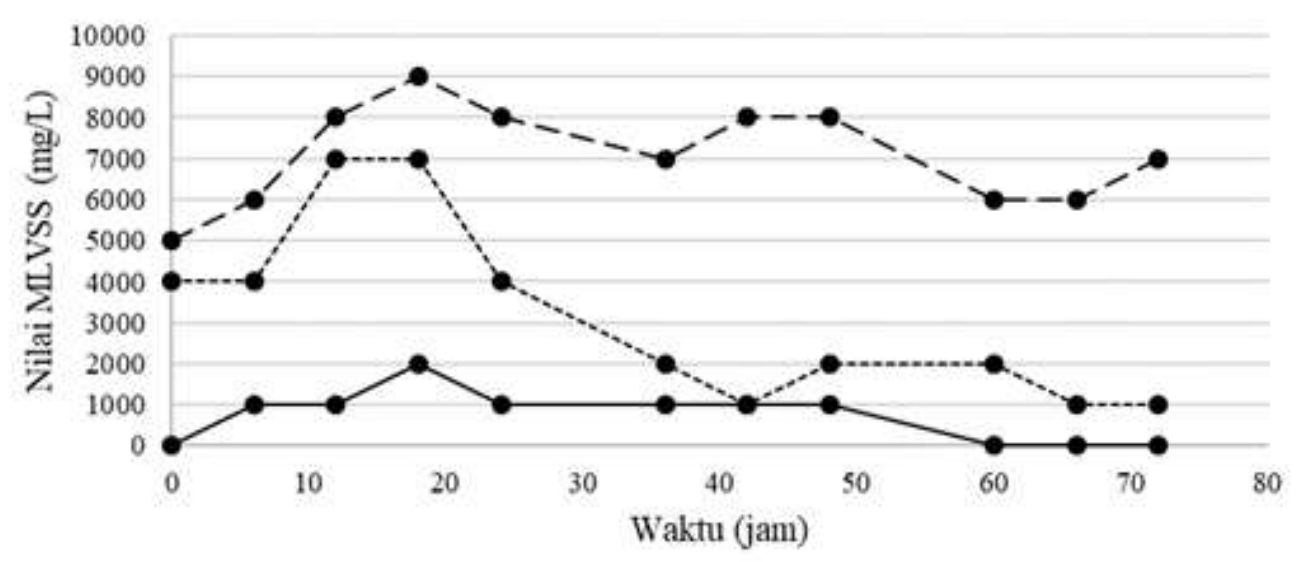

Gambar 1.

Nilai MLVSS pada Proses Pembibitan Suspensi Aktif dengan Waktu Pengolahan Selama Tiga Hari

Keterangan:

$$
\begin{aligned}
& =\text { Media } 1 \\
------ & =\text { Media } 2 \\
\ldots \ldots . & =\text { Media } 3
\end{aligned}
$$

Gambar 1. menunjukkan bahwa terdapat perbedaan nilai MLVSS antara ketiga media. Jam ke-0 media I memiliki nilai MLVSS sebesar $0 \mathrm{mg} / \mathrm{L}$ artinya belum terlihat adanya pertumbuhan mikroorganisme, nilai MLVSS media II pada jam ke-0 adalah sebesar $5000 \mathrm{mg} / \mathrm{L}$ dan nilai MLVSS media III jam ke-0 adalah sebesar $4000 \mathrm{mg} / \mathrm{L}$, hal tersebut menunjukkan adanya aktivitas mikrooganisme pada media II dan media III. Nilai MLVSS akan semakin meningkat setelah dilakukan aerasi selama beberapa jam, hal tersebut karena mikroorganisme telah beradaptasi dengan lingkungan barunya yang disebut dengan tahap aklimatisasi. Mikroorganisme akan mengalami fase pertumbuhan eksponensial atau fase logaritmik yaitu mikroorganisme akan terus tumbuh dan berkembang dengan cepat karena kebutuhan nutrisi berupa senyawa organik sebagai sumber karbon dan nutrient tersedia yang digunakan untuk pertumbuhannya dapat diperoleh dengan 
mudah sehingga mikroorganisme mampu beraktivitas dan menguraikan bahan-bahan anorganik ataupun bahan-bahan organik yang ada (Sudaryati dkk, 2012).

Mikroorganisme akan mengalami fase pembiakan diperlambat. Fase ini ditandai dengan penurunan nilai MLVSS, serta jumlah mikroorganisme yang mati jumlahnya hampir sama dengan jumlah mikroorganisme yang hidup. Mikroorganisme tetap hidup apabila persediaan nutrient dan kebutuhan oksigen terlarut melalui proses aerasi pada suspensi aktif masih tersedia (Mantyasno, 2012).

Penelitian Suyasa dkk (2018) menyebutkan bahwa puncak pertumbuhan biomassa dengan menggunakan media pupuk NPK dan glukosa terjadi pada jam ke-18 dengan nilai MLVSS sebesar 1200 $\mathrm{mg} / \mathrm{L}$, sedangkan menurut Pradnyadari dkk (2018) tingkat pertumbuhan biomassa dengan media pupuk $\mathrm{NPK}, \mathrm{NH}_{4} \mathrm{Cl}$, dan glukosa serta penambahan suspensi aktif memiliki nilai MLVSS sebesar $4420 \mathrm{mg} / \mathrm{L}$ pada jam ke-42. Jika dibandingkan dengan hasil penelitian yang diperoleh, pada fase pertumbuhan cepat dengan puncak pertumbuhan biomassa yang tertinggi terjadi pada media I dengan nilai MLVSS sebesar $2000 \mathrm{mg} / \mathrm{L}$ terjadi pada jam ke-18, media II dengan nilai MLVSS $9000 \mathrm{mg} / \mathrm{L}$ terjadi pada jam ke-18, dan pada media III nilai MLVSS sebesar $7000 \mathrm{mg} / \mathrm{L}$ terjadi pada jam ke-12. Media dengan nilai MLVSS tertinggi didapat pada media II dengan komposisi 5 gram pupuk NPK; 2,5 gram $\mathrm{NH}_{4} \mathrm{Cl}$; dan 5 gram glukosa. Perbedaan nilai MLVSS dengan penelitian yang telah dilakukan sebelumnya disebabkan oleh adanya perbedaan sumber suspensi aktif dan komposisi nutrient yang digunakan.

\subsection{Pengukuran Kadar Air pada Pellet Ammonia Oxidizers}

Hasil pengukuran kadar air pada pellet yang diperoleh disajikan pada Tabel 1 .
Tabel 1. Data Pengukuran Kadar Air pada Pellet

\begin{tabular}{cc}
\hline Pellet & $\begin{array}{c}\text { Kadar air } \\
(\%)\end{array}$ \\
\hline 1. & $8,50 \%$ \\
2. & $8,41 \%$ \\
3. & $8,91 \%$ \\
\hline Rata-rata & $8,61 \%$ \\
\hline
\end{tabular}

Pellet yang dibuat memiliki bentuk tabung, dengan panjang $\pm 3 \mathrm{~cm}$ dengan diameter $\pm 1 \mathrm{~cm}$. Pellet tersebut berwarna kuning pudar dengan bau yang tidak menyengat. Berat rata-rata satu buah pellet adalah $\pm 2,00$ gram. Pembuatan pellet memiliki parameter yang harus diuji agar pellet yang dihasilkan dapat digunakan untuk proses selanjutnya. Parameter yang diuji pada pellet tersebut adalah pengukuran kadar air pellet. Berdasarkan Tabel 1. ratarata kadar air pada pellet tersebut adalah sebesar $8,61 \%$, hasil tersebut menunjukkan bahwa kadar air yang diperoleh sudah memenuhi standar baku mutu pembuatan pellet. Kadar air yang baik untuk proses pengeringan pellet adalah tidak lebih dari 10\% (Edison dkk, 2011). Pellet yang kadar airnya telah memenuhi standar baku akan membuat pellet tidak mudah ditumbuhi oleh jamur.

\subsection{Parameter pada Proses Pengolahan Urin Kambing menjadi Pupuk N}

Parameter pada proses pengolahan urin kambing dengan penambahan pellet agar menjadi pupuk $\mathrm{N}$ adalah pengukuran kadar amonia, nitrit, nitrat, $\mathrm{pH}$ dan temperatur.

\subsubsection{Perubahan kadar amonia pada berbagai dosis pellet pada pengolahan urin kambing menjadi pupuk $\mathbf{N}$}

Hasil kadar amonia pada sampel urin kambing pada proses pengolahan selama 24 jam disajikan dalam Tabel 2. 
Tabel 2. Data Perubahan Kadar Amonia pada Berbagai Dosis Pellet pada Proses Pengolahan Urin Kambing menjadi Pupuk N

Dosis Pellet (\%) Waktu (jam) Rata-rata Konsentrasi Amonia (mg/L) \pm Standar Deviasi

\begin{tabular}{ccc}
\hline & 0 & $9,6223 \pm 0,0161$ \\
10 & 8 & $8,9914 \pm 0,0828$ \\
& 12 & $8,6508 \pm 0,0161$ \\
& 18 & $8,3147 \pm 0,0354$ \\
& 24 & $7,1819 \pm 0,0767$ \\
\hline \multirow{2}{*}{20} & 0 & $9,6332 \pm 0,0352$ \\
& 8 & $8,2954 \pm 0,0462$ \\
& 12 & $6,9924 \pm 0,0754$ \\
& 18 & $5,6811 \pm 0,0343$ \\
& 24 & $5,8815 \pm 0,0174$ \\
\hline \multirow{2}{*}{30} & 0 & $9,6190 \pm 0,0275$ \\
& 8 & $8,4026 \pm 0,0338$ \\
& 12 & $7,1523 \pm 0,0471$ \\
& 24 & $6,9726 \pm 0,0675$ \\
\hline
\end{tabular}

Grafik perubahan kadar amonia pada berbagai dosis pellet pada proses pengolahan urin kambing menjadi pupuk $\mathrm{N}$ disajikan dalam Gambar 2.

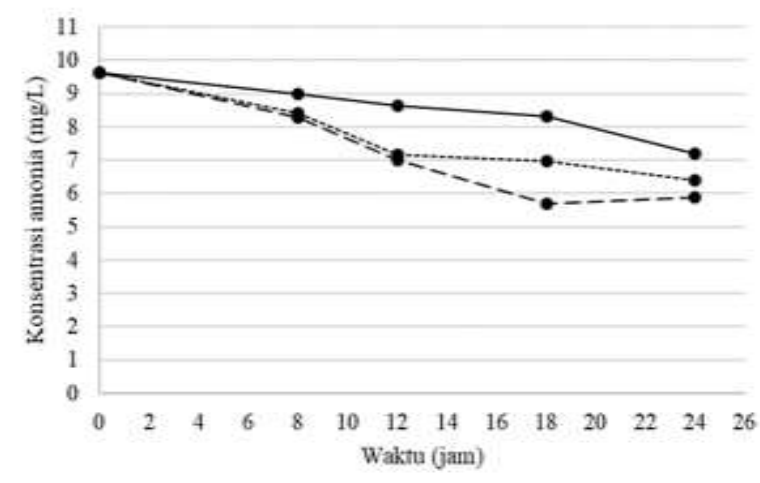

Gambar 2.

Penurunan Kadar Amonia pada Berbagai

Dosis Pellet pada Proses Pengolahan Urin Kambing Menjadi Pupuk N

Keterangan:

$-=$ dosis pellet $10 \%(\mathrm{~b} / \mathrm{v})$;

---- $=$ dosis pellet $20 \%(\mathrm{~b} / \mathrm{v})$;

$\ldots . .=$ dosis pellet $30 \%(\mathrm{~b} / \mathrm{v})$
Berdasarkan grafik pada Gambar 2. menunjukkan adanya penurunan kadar amonia pada sampel baik itu dengan dosis pellet $10 \%(\mathrm{~b} / \mathrm{v}), 20 \%(\mathrm{~b} / \mathrm{v})$ maupun $30 \%$ $(\mathrm{b} / \mathrm{v})$. Sampel dengan dosis pellet $10 \%(\mathrm{~b} / \mathrm{v})$ memiliki kadar amonia terendah sebesar 7,1819 mg/L yang terjadi pada jam ke-24. Sampel dengan dosis pellet $20 \%$ (b/v) mengalami penurunan kadar amonia terendah pada jam ke-18 dengan kadar amonia sebesar 5,611 $\mathrm{mg} / \mathrm{L}$, kemudian sampel dengan dosis pellet $30 \% \quad(\mathrm{~b} / \mathrm{v})$ mengalami penurunan kadar amonia terendah pada jam ke-24 dengan kadar amonia sebesar 6,3887 $\mathrm{mg} / \mathrm{L}$. Penurunan kadar amonia terendah seiring dengan lamanya waktu pengolahan terlihat pada sampel dengan dosis pellet $20 \%$ (b/v) pada jam ke-18 dengan kadar amonia sebesar $5,611 \mathrm{mg} / \mathrm{L}$.

Hasil tersebut berbeda dengan hasil penelitian yang telah dilakukan sebelumnya oleh Vanotti dan Hunt (2000) dimana dosis pellet optimal yang diperoleh adalah $15 \%$ (b/v) dengan waktu pengolahan optimal pada jam ke-14, sedangkan penelitian Szogi 
dkk (2004) waktu pengukuran optimal diperoleh pada jam ke-12. Perbedaan tersebut terjadi karena perbedaan pellet yang digunakan untuk pengolahan. Senyawa amonia yang terkandung dalam urin dapat diturunkan konsentrasiya secara mikrobiologi dengan melalui proses nitrifikasi yang mengubah amonia menjadi nitrit dan nitrat dengan bantuan oksigen melalui proses aerasi.

Aktivitas mikroorganisme yang terimobilisasi dalam pellet menyebabkan penurunan kadar amonia. Mikroorganisme Nitrosomonas mengubah amonia menjadi nitrit pada proses nitritasi, dengan persamaan reaksi sebagai berikut : (Wielgosz dkk, 2010).

$2 \mathrm{NH}_{4}{ }^{+}+3 \mathrm{O}_{2} \stackrel{\text { Nitrsomonas }}{\longrightarrow} 2 \mathrm{NO}_{2}{ }^{-}+2 \mathrm{H}_{2} \mathrm{O}+4 \mathrm{H}^{+}$

\subsubsection{Perubahan Kadar Nitrit pada Berbagai Dosis Pellet pada Proses Pengolahan Urin Kambing Menjadi Pupuk N}

Hasil kadar nitrit pada sampel urin kambing pada proses pengolahan selama 24 jam disajikan dalam Tabel 3.

Tabel 3. Data Perubahan Kadar Nitrit pada Berbagai Dosis Pellet pada Proses Pengolahan Urin Kambing menjadi Pupuk N

\begin{tabular}{|c|c|c|}
\hline Dosis Pellet (\%) & Waktu (jam) & $\begin{array}{c}\text { Rata-rata Konsentrasi Nitrit }(\mathrm{mg} / \mathrm{L}) \pm \text { Standar } \\
\text { Deviasi }\end{array}$ \\
\hline \multirow{5}{*}{10} & 0 & $8,2998 \pm 0,0248$ \\
\hline & 8 & $7,6875 \pm 0,0418$ \\
\hline & 12 & $5,2599 \pm 0,0306$ \\
\hline & 18 & $4,2637 \pm 0,0227$ \\
\hline & 24 & $4,6940 \pm 0,0320$ \\
\hline \multirow{5}{*}{20} & 0 & $8,3408 \pm 0,0145$ \\
\hline & 8 & $5,8986 \pm 0,0327$ \\
\hline & 12 & $4,9027 \pm 0,0343$ \\
\hline & 18 & $2,3992 \pm 0,0283$ \\
\hline & 24 & $3,5111 \pm 0,0216$ \\
\hline \multirow{5}{*}{30} & 0 & $8,3098 \pm 0,0165$ \\
\hline & 8 & $6,1147 \pm 0,0250$ \\
\hline & 12 & $5,0215 \pm 0,0180$ \\
\hline & 18 & $4,6013 \pm 0,03659$ \\
\hline & 24 & $2,9084 \pm 0,0357$ \\
\hline
\end{tabular}


Grafik perubahan kadar nitrit pada berbagai konsentrasi pada proses pengolahan urin kambing menjadi pupuk $\mathrm{N}$ disajikan dalam Gambar 3.

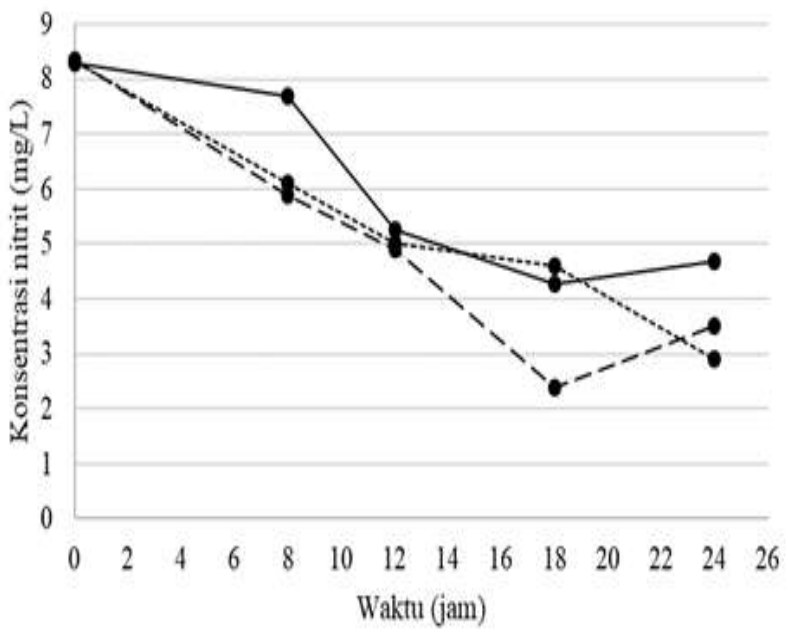

Gambar 3.

Perubahan Kadar Nitrit pada Berbagai Dosis

Pellet pada Proses Pengolahan Urin Kambing Menjadi Pupuk N

Keterangan:

$-=$ dosis pellet $10 \%(\mathrm{~b} / \mathrm{v})$

----- $=$ dosis pellet $20 \%(\mathrm{~b} / \mathrm{v})$

$\ldots . . .=$ dosis pellet $30 \%(\mathrm{~b} / \mathrm{v})$

Berdasarkan grafik pada Gambar 3. menunjukkan adanya penurunan konsentrasi nitrit pada ketiga sampel dengan dosis berbeda-beda. Urin kambing yang diolah dengan dosis pellet $10 \%(\mathrm{~b} / \mathrm{v})$ mengalami penurunan kadar nitrit, penurunan tersebut terjadi pada jam ke-18 dengan kadar nitrit sebesar 4,2637 $\mathrm{mg} / \mathrm{L}$. sampel dengan dosis pellet $20 \% \quad(\mathrm{~b} / \mathrm{v})$ mengalami penurunan kadar nitrit paling rendah pada jam ke-18 dengan kadar nitrit sebesar 2,3992 $\mathrm{mg} / \mathrm{L}$, sedangkan pada sampel dengan dosis pellet $30 \%$ (b/v) memiliki kadar nitrit terendah sebesar 2,9084 yang terjadi pada jam ke-24.
Penurunan paling signifikan terjadi pada sampel dengan dosis pellet $20 \%$ (b/v) pada jam ke-18 dengan kadar nitrit sebesar 2,3992 mg/L.

Penurunan kadar nitrit terjadi karena adanya proses pengoksidasian amonia dengan bantuan bakteri yang terimobilisasi dalam pellet serta dengan bantuan oksigen melalui proses aerasi, tetapi jumlah nitrit yang diperoleh tidak banyak karena nitrit yang dihasilkan akan cepat mengalami proses oksidasi oleh bakteri aerob sehingga menjadi nitrat (Zilfa dkk, 2012). Sampel dengan dosis pellet $10 \% \quad(\mathrm{~b} / \mathrm{v})$ kurang optimal dalam menurunkan kadar nitrit karena jumlah atau populasi mikroorganisme yang ada pada sampel lebih sedikit, sehingga proses oksidasi kurang optimal, sedangkan pada sampel dengan dosis pellet $30 \%$ (b/v) kurang optimal pula dalam penurunan kadar nitrit karena suplai oksigen yang kurang dan populasi mikroorganisme terlalu banyak namun kebutuhan oksigen untuk proses oksidasi kurang mencukupi sehingga hasil yang diperoleh kurang optimal. Selain itu pada dosis pellet $30 \%(\mathrm{~b} / \mathrm{v})$ memiliki nilai $\mathrm{pH}$ yang paling rendah daripada sampel dengan dosis pellet $10 \%(\mathrm{~b} / \mathrm{v})$ dan $20 \%(\mathrm{~b} / \mathrm{v})$, sehingga proses nitrifikasi yang terjadi kurang optimal karena pada $\mathrm{pH}$ yang terlalu rendah efektifitas nitrifikasi akan semakin menurun.

\subsubsection{Perubahan kadar nitrat pada berbagai dosis pellet pada proses pengolahan urin kambing menjadi pupuk N}

Hasil kadar nitrat pada sampel urin kambing pada proses pengolahan selama 24 jam disajikan dalam Tabel 4. 
Tabel 4. Data Perubahan Kadar Nitrat pada Berbagai Dosis Pellet pada Proses Pengolahan Urin Kambing menjadi Pupuk N

\begin{tabular}{ccc}
\hline \multirow{2}{*}{ Dosis Pellet $(\%)$} & Rata-rata Konsentrasi Nitrat $(\mathrm{mg} / \mathrm{L}) \pm$ \\
& 0 & Standar Deviasi \\
\hline \multirow{3}{*}{10} & 8 & $7,2740 \pm 0,0866$ \\
& 12 & $7,8365 \pm 0,1180$ \\
& 18 & $9,4952 \pm 0,1322$ \\
24 & $9,7740 \pm 0,1012$ \\
20 & 0 & $9,4663 \pm 0,1471$ \\
\hline \multirow{3}{*}{30} & 12 & $7,3285 \pm 0,0546$ \\
& 18 & $7,9904 \pm 0,1466$ \\
& 24 & $9,2468 \pm 0,0264$ \\
& 0 & $10,6618 \pm 0,0466$ \\
& 8 & $9,3942 \pm 0,0961$ \\
\hline \multirow{2}{*}{30} & $7,3686 \pm 0,0308$ \\
& 12 & $8,4214 \pm 0,1066$ \\
& 24 & $9,3365 \pm 0,0928$ \\
& & $9,9839 \pm 0,1114$ \\
\hline
\end{tabular}

Grafik perubahan kadar nitrat pada berbagai dosis pellet pada proses pengolahan urin kambing menjadi pupuk $\mathrm{N}$ disajikan dalam Gambar 4.

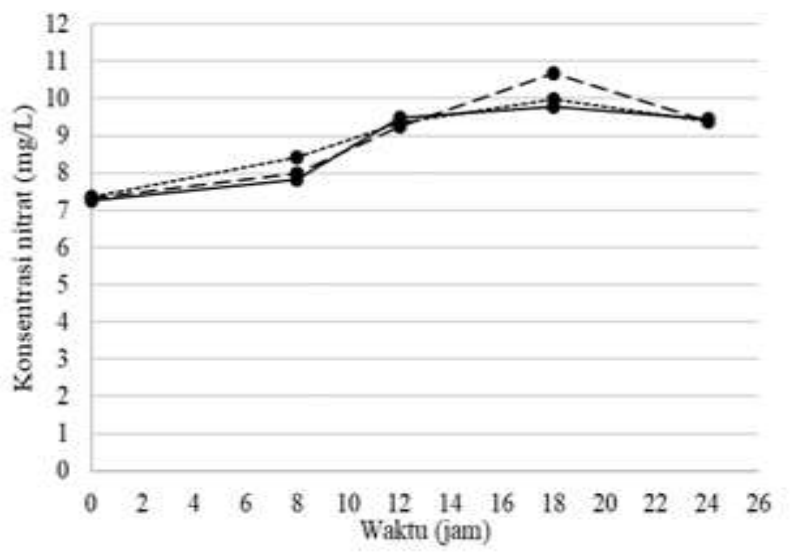

Gambar 4.

Perubahan Kadar Nitrat pada Berbagai

Dosis Pellet pada Proses Pengolahan Urin Kambing Menjadi Pupuk N

Keterangan:

$-=$ dosis pellet $10 \%(\mathrm{~b} / \mathrm{v})$;

---- $=$ dosis pellet $20 \%(\mathrm{~b} / \mathrm{v})$;

$=$ dosis pellet $30 \%(\mathrm{~b} / \mathrm{v})$
Berdasarkan grafik pada Gambar 4. terlihat bahwa kadar nitrat pada ketiga sampel dengan berbagai dosis pellet mengalami kenaikan. Kenaikan kadar nitrat yang tertinggi seiring dengan lamanya waktu pengolahan terlihat pada sampel dengan dosis pellet $20 \%(\mathrm{~b} / \mathrm{v})$ dan waktu pengukuran pada jam ke-18 dengan kadar nitrat sebesar 10,6618 mg/L. Sampel dengan dosis pellet $10 \%(\mathrm{~b} / \mathrm{v})$ dan $30 \% \quad(\mathrm{~b} / \mathrm{v})$ mengalami kenaikan kadar nitrat yang tertinggi pada jam ke-18 dengan kadar nitrat rata-rata untuk sampel dengan dosis pellet $10 \%$ (b/v) sebesar 9,7740 $\mathrm{mg} / \mathrm{L}$, dan ratarata kadar nitrat untuk sampel dengan dosis pellet $30 \% \quad(\mathrm{~b} / \mathrm{v})$ adalah sebesar 9,9839 $\mathrm{mg} / \mathrm{L}$. Kenaikan kadar nitrat disebabkan karena adanya proses oksidasi amonia menjadi nitrit kemudian dioksidasi lagi menjadi nitrat yang disebut dengan reaksi nitrifikasi. Tahap pembentukan nitrat ini dinamakan tahap nitratasi. Bakteri yang berperan pada tahap ini adalah bakteri Nitrobacter dengan kondisi aerob, dengan persamaan reaksi sebagai berikut: (Wielgosz dkk, 2010). 


$$
\mathrm{NO}_{2}{ }^{-}+1 / 2 \mathrm{O}_{2} \stackrel{\text { Nitrobacter }}{\longrightarrow} \mathrm{NO}_{3}{ }^{-}
$$

Aktivitas bakteri Nitrobacter pada proses nitrifikasi dipengaruhi oleh nilai $\mathrm{pH}$ dan temperatur. Apabila nilai $\mathrm{pH}$ terlalu tinggi atau terlalu rendah maka proses nitrifikasi akan terhenti, sehingga pada penelitian ini juga dilakukan pengukuran nilai $\mathrm{pH}$ dan temperatur.

\subsubsection{Perubahan pH pada Berbagai Dosis Pellet pada Pengolahan Urin Kambing Menjadi Pupuk N}

Hasil penngukuran $\mathrm{pH}$ selama proses pengolahan urin kambing menjadi pupuk $\mathrm{N}$ disajikan dalam Gambar 5.

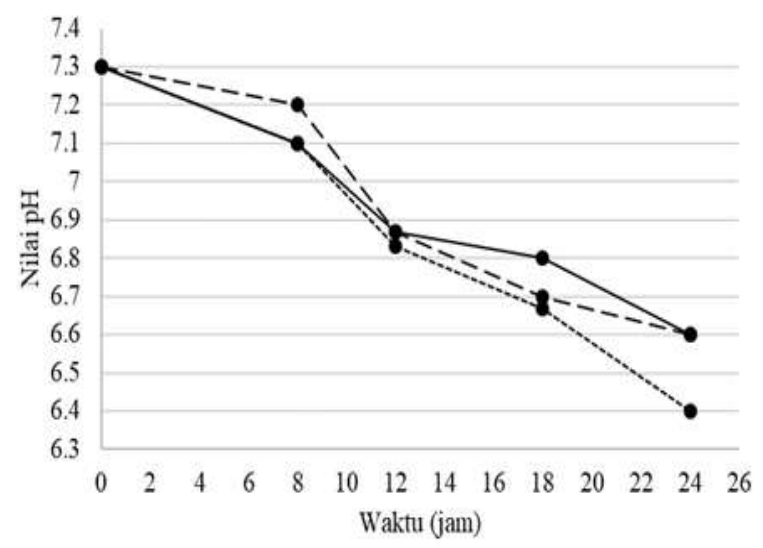

Gambar 5.

Perubahan pH pada Berbagai Dosis Pellet pada Proses Pengolahan Urin Kambing Menjadi Pupuk N

Keterangan:

$-=$ dosis pellet $10 \%(\mathrm{~b} / \mathrm{v})$

----- $=$ dosis pellet $20 \%(\mathrm{~b} / \mathrm{v})$

$\ldots . . .=$ dosis pellet $30 \%(\mathrm{~b} / \mathrm{v})$

Berdasarkan data pengukuran $\mathrm{pH}$ pada Gambar 5. terlihat nilai $\mathrm{pH}$ dari ketiga sampel dengan dosis pellet $10 \%(\mathrm{~b} / \mathrm{v}), 20 \%$ (b/v), dan $30 \%$ (b/v) mengalami penurunan. Nilai $\mathrm{pH}$ menurun seiring dengan penurunan kadar amonia. Penurunan $\mathrm{pH}$ disebabkan oleh adanya proses nitrifikasi. Reaksi nitrifikasi tahap nitritasi selain menghasilkan ion $\mathrm{NO}_{2}^{-}$juga akan melepaskan ion $\mathrm{H}^{+}$dan $\mathrm{H}_{2} \mathrm{O}$. Ion $\mathrm{H}^{+}$tersebut menyebabkan terjadinya penurunan $\mathrm{pH}$. Hal tersebut karena ion $\mathrm{H}^{+}$memiliki sifat asam, sehingga nilai $\mathrm{pH}$ semakin menurun (Nurlita dan Utomo, 2011). Apabila amonia mengalami peningkatan maka nilai $\mathrm{pH}$ juga akan meningkat. Sebagian besar amonia akan terionisasi pada $\mathrm{pH} 7$ atau kurang, dan sebaliknya, amonia tidak terionisasi pada $\mathrm{pH}$ lebih besar dari 7 dan bersifat toksik. pH optimal nitrifikasi adalah sebesar 7,5-8,5.

Data di atas menunjukkan penurunan nilai $\mathrm{pH}$ pada setiap dosis pellet tidak mencapai $\mathrm{pH} 5$, sehingga proses nitrifikasi belum terhenti, hanya saja proses yang berlangsung memiliki efektifitas yang menurun dan hasil oksidasi amonia kurang optimal pada $\mathrm{pH}$ yang terlalu rendah. Nilai $\mathrm{pH}$ terendah terdapat pada sampel dengan dosis $30 \%(\mathrm{~b} / \mathrm{v})$ yaitu sebesar 6,4 yang berarti proses nitrifikasi masih dapat berlangsung dan belum terhenti tetapi efektifitasnya menurun.

\subsubsection{Perubahan Temperatur pada Berbagai Dosis Pellet pada Proses Pengolahan Urin Kambing Menjadi Pupuk N}

Hasil pengukuran temperatur selama proses pengolahan urin kambing menjadi pupuk N disajikan dalam Gambar 6.

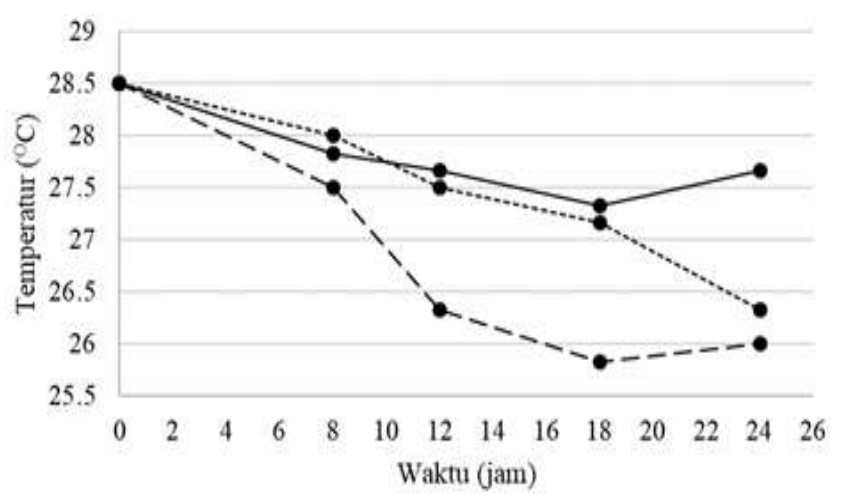

Gambar 6.

Perubahan Temperatur pada Berbagai Dosis

Pellet pada Proses Pengolahan Urin Kambing Menjadi Pupuk N

Keterangan:

$-=$ dosis pellet $10 \%(\mathrm{~b} / \mathrm{v})$

$-----=$ dosis pellet $20 \%(\mathrm{~b} / \mathrm{v})$

$\ldots \ldots=$ dosis pellet $30 \%(\mathrm{~b} / \mathrm{v})$ 
Berdasarkan Gambar 6. dapat dilihat bahwa pada sampel dengan dosis pellet $10 \%$ (b/v) mengalami penurunan temperatur pada jam ke-8 hingga jam ke-24, sedangkan sampel dengan dosis pellet $20 \%$ (b/v) dan $30 \%(\mathrm{~b} / \mathrm{v})$ mengalami penurunan temperatur pada jam ke-8, 12 dan jam ke-18 kemudian pada jam ke-24 temperatur mengalami kenaikan. Perubahan temperatur hanya mencapai rentang $0,5^{\circ} \mathrm{C}$ hingga $1^{\circ} \mathrm{C}$ per variasi waktu pengukuran. Apabila rentang perubahan temperatur tinggi, maka kemungkinan terjadi pertumbuhan jamur pada pellet. Temperatur yang terukur pada setiap sampel tidak melebihi batas temperatur optimal dari bakteri nitrifikasi, sehingga pada temperatur tersebut proses nitrifikasi berlangsung dengan baik.

\section{SIMPULAN DAN SARAN}

\subsection{Simpulan}

1. Perbedaan komposisi nutrient berpengaruh terhadap pertumbuhan biomassa (MLVSS) mikroorganisme nitrifikasi karena pada ketiga variasi nutrient memberikan hasil pertumbuhan biomassa dengan nilai yang berbedabeda, dimana pertumbuhan biomassa paling baik adalah pada media II (pupuk NPK, $\mathrm{NH}_{4} \mathrm{Cl}$, dan glukosa). Nilai MLVSS pada masa pertumbuhan yaitu $9000 \mathrm{mg} / \mathrm{L}$ dengan waktu pertumbuhan optimal pada jam ke-18.

2. Dosis pellet ammonia oxidizers berpengaruh terhadap proses nitrifikasi urin kambing menjadi pupuk $\mathrm{N}$ karena pada ketiga variasi dosis pellet diperoleh kadar amonia, nitrit dan nitrat yang berbeda-beda. Perubahan kadar amonia, nitrit, dan nitrat yang paling baik diperoleh pada dosis pellet 20\% karena pada dosis tersebut populasi bakteri pengoksidasi amonia, suplai oksigen dan pengukuran $\mathrm{pH}$ serta temperaturnya berada pada kondisi optimal.
3. Pada penelitian ini diperoleh waktu pengolahan yang paling optimal pada jam ke-18 karena setelah jam ke-18 kemungkinan terjadi penurunan populasi bakteri, sehingga proses nitrikasi oleh bakteri nitrifiers tidak optimal. Oleh karena itu waktu pengolahan berpengaruh terhadap proses nitrifikasi urin kambing menjadi pupuk N.

\subsection{Saran}

Perlu dilakukan pengukuran kadar $\mathrm{P}$ dan $\mathrm{K}$ pada urin kambing yang telah diolah menjadi pupuk $\mathrm{N}$ serta perlu dilakukan pengujian pupuk $\mathrm{N}$ terhadap tanaman.

\section{DAFTAR PUSTAKA}

Edison, S., Aslamyah, S., Salam, N.I. 2011. Kualitas Pakan Buatan Udang Windu yang Menggunakan Berbagai Dosis Tepung Rumput Laut (Gracilaria gigas) sebagai Bahan Perekat. Jurnal Akuakultur Indonesia. 10: 59-66.

Lingga, P. 1991. Jenis dan Kandungan Hara pada Beberapa Kotoran Ternak. Pusat Pelatihan Pertanian dan Pedesaan Swadaya (P4S) Antanan. Bogor.

Mantyasno, A.T. 2012. Penurunan Amoniak dan $\mathrm{H}_{2} \mathrm{~S}$ pada Air Limbah Rumah Potong Hewan Sapi dengan Proses Biofilter Bermedia Kombinasi Anaerob Aerob Bermedia Potongan Plastik untuk Media Hidup Ikan Budidaya. Jurnal Lingkungan. 1(2): 134-141.

Nurlita, H dan Utomo, S. 2011. Potensi Nitrifikasi oleh Bakteri yang Terdapat di Laut Aliran Kali Plumbon, Laut Aliran Kali Banjir Kanal Barat dan Laut Aliran Kali Banjir Kanal Timur. Jurnal Presipitasi. 8(1): 1-7. 
Pradnyadari, I.G.A.L., Suyasa, I.W.B., Suastuti, N.G.A.M.D.A. 2018. Penyisihan Amonia Nitrit dan Nitrat dengan Biofilter Menggunakan Plastik Bekas sebagai Media Penopang Biofilm. Jurnal Media Sains. 2(2): 76-82.

Sudaryati, N.L.G., Kasa, I.W., Suyasa, I.W.B. 2012. Pemanfaatan Sedimen Perairan Tercemar sebagai Bahan Lumpur Aktif dalam Pengolahan Limbah Cair Industri Tahu. Ecotrophic. 3(1): 21-29.

Suyasa, I.W.B., Suastuti, N.G.A.M.D.A., Raharja, I.G.M.A. 2018. Inokulasi Suspensi Aktif pada Biosistem Vertikal dengan Tumbuhan Rumput Gajah (Pennisetum purpureum) dalam Penurunan Kadar Metilen Biru, Cd, dan $\mathrm{Cr}$ Total. Jurnal Kimia. 12(2): 107115.

Szogi, A.A, Vanotti, M.B., Rice, J.M., Humenik, J., Hunt, P.G. 2004. Nitrification Options for Pig
Wastewater Treatment. New Zealand Journal of Agricultural Research. 47(4): 439-448.

Vanotti, M.B., dan Hunt, P.G. 2000. Nitrification Treatment of Swine Wastewater with Acclimated Nitrifiying Sludge Immobilized in Polymer Pellets. Transactions of the ASAE. 43(2): 405-413.

Wielgosz, E., Jozwiakowski, K., Bielinska, E.J. 2010. Numbers of Ammonifying, Nitrifying and Denitrifying Bacteria in Sewage Treated in A System of Biological Stabilisation Ponds. Department of Agricultural Mikrobiology University of Life Sciences. Lublin.

Zilfa, Zulfarman, Hariyanti. 2012. Penentuan Tingkat Kandungan Amoniak, Nitrit, Nitrat pada Rembesan Sampah Lokasi Pembuangan Akhir (LPA) Air Dingin Kota Padang. J.Ris.Kim. 5(2): 195-200. 